\title{
Peningkatan Hasil Belajar Permainan Voli Dengan Metode Variasi Di SMA Negeri 2 Siak Hulu
}

\author{
Yus Yetti \\ SMA Negeri 2 Siak Hulu \\ e-mail: yusyetti19@gmail.com
}

\begin{abstract}
The issue is low learning results in volleyball games for students in SMA Negeri 2 Siak Hulu class XI Social Sciences. Most students can't pass over effectively and appropriately, and they're not interested in mastering passing over. Affects student learning outcomes This study aimed to improve the learning outcomes of passing over in volleyball games for SMA Negeri 2 Siak Hulu class XI IPS students. The study ran from July to October 2019. Classroom Action Research) with 59 students from class XI IPS, with 30 from class XI IPS.1 and 29 from class XI IPS.2. The data was collected through observation utilizing a volleyball passing skill test instrument. The results showed that using the variety approach in the volleyball game of passing learning activities increased passing learning outcomes for Class XI Social Sciences students by 72.88 percent in cycle 1, and 89.81 percent in cycle 2. good to excellent category This result suggests that students enjoy the material offered and desire to participate directly in learning since the material is enjoyable. Student engagement increased by 74.58 percent in cycle 1 and by 91.53 percent in cycle 2. Thus, the effective variation approach is employed in class XI IP SMA students to increase learning outcomes of passing over in volleyball.
\end{abstract}

Keywords: Classroom Action Research, Learning Outcomes, Passing Volleyball, Variation Method

\begin{abstract}
Abstrak
Siswa kelas XI IPS SMA Negeri 2 Siak Hulu bertekad telah mempelajari passing bawah dalam bola voli selama investigasi ini. kecil kemungkinannya untuk mencurahkan waktu dan upaya untuk menyelesaikannya. Hal ini berdampak pada prestasi siswa. Tujuan penelitian ini adalah untuk membantu siswa kelas XI IPS SMA Negeri 2 Siak Hulu dalam memahami passing bawah dalam permainan bola voli dengan menggunakan pendekatan ragam. Antara Juli dan Oktober tahun ini, para peneliti melakukan penyelidikan mereka. Peserta didik kelas XI IPS.1 dan XI IPS.2 merupakan mayoritas peserta penelitian (Penelitian Tindakan Kelas atau disingkat PTK) yang melibatkan total 59 peserta. Instrumen tes keterampilan passing untuk permainan bola voli digunakan sebagai metode pengumpulan data. Siswa kelas XI IPS mengalami peningkatan hasil belajar passing bawah sebesar 72,88 persen pada siklus 1 setelah dilakukan penerapan strategi variasi dalam permainan bola voli; pada siklus 2 terjadi peningkatan ketuntasan hasil belajar sebesar 89,81 persen. layak tetapi tidak luar biasa. Hal ini menunjukkan bahwa strategi variasi dapat memotivasi siswa untuk berpartisipasi aktif dalam proses pembelajaran karena materi yang disampaikan dianggap menyenangkan. Peningkatan keterlibatan siswa sebesar 74,58 persen pada Siklus 1 dan peningkatan 91,53 persen pada Siklus 2 dapat dikaitkan dengan hal ini. Dengan demikian dapat dikatakan bahwa siswa kelas XI IP SMA diajarkan passing atas bola voli dengan teknik variasi yang efektif
\end{abstract}

Kata kunci: Penelitian Tindakan Kelas, Hasil Belajar, Passing atas Bola Voli , Metode Variasi

\section{PENDAHULUAN}

Olahraga, kebugaran, dan kesehatan adalah semua bentuk pendidikan jasmani. Agar anak menjadi generasi penerus pemimpin bangsa, pendidikan jasmani, olahraga dan kesehatan harus menjadi bagian dari kurikulum mereka (Lestari, 2007:1).

Pertumbuhan dan perkembangan siswa mengharuskan pendidikan jasmani, olahraga, dan kesehatan diajarkan di sekolah sedemikian rupa sehingga memudahkan pengajar untuk mengajar secara optimal(Mulyasa. 2010). Bola voli, khususnya, adalah olahraga yang mendebarkan untuk ditonton. Guru harus menggunakan teknik variasi untuk menciptakan kegiatan pembelajaran yang membuat pelaksanaan pendidikan bola voli menyenangkan bagi siswa. 
Untuk menghindari siswa menjadi bosan dan bosan saat belajar, Harsono (1988:121) merekomendasikan menggunakan pendekatan ragam. Siswa tidak akan bosan dengan materi yang sulit, seperti menguasai keterampilan teknik over-passing, jika menggunakan metode variasi dalam permainan bola voli.

Sudah sulit bagi sebagian besar siswa untuk memperoleh teknik passing. Memecahkan masalah ini melalui penggunaan pendekatan variasi dalam kegiatan pendidikan dapat mendorong siswa untuk berpartisipasi penuh dalam kegiatan pendidikan karena dianggap menyenangkan. Hasil belajar siswa kelas XI IPS diharapkan dapat mengambil manfaat dari proyek ini, diharapkan.

\section{METODE}

Penelitian ini merupakan penelitian tindakan kelas. Semua siswa kelas XI IPS.1 dan XI IPS.2 di SMA Negeri 2 Siak Hulu yang memiliki keterkaitan dengan kegiatan pembelajaran passing atas diikutsertakan dalam penelitian ini. Subyek dipilih berdasarkan ketergantungan, kerumitan, dan kelengkapan informasi yang dikumpulkan. Ada 59 siswa kelas XI IPS yang menjadi subjek penelitian ini. Penelitian dilaksanakan di SMA Negeri 2 Siak Hulu, Kecamatan Siak Hulu, Kabupaten Kampar, Provinsi Riau.

Setelah peneliti menyiapkan segala sesuatu, maka perlu dilakukan langkah-langkah adalah sebagai berikut:

1. Menyusun rencana tindakan

Mempersiapkan rencana tindakan memerlukan pembuatan kerangka penelitian yang mendefinisikan apa, mengapa, kapan, di mana, oleh siapa, dan bagaimana tindakan akan dilakukan melalui penggunaan metode pelatihan dan pembuatan instrumen penelitian.

2. Penyajian tindakan

Penerapan isi rencana aksi adalah penyajian aksi atau realisasi aksi. Penyajian tindakan dilakukan dalam siklus yang berkesinambungan. Peneliti harus mematuhi apa yang telah dinyatakan dalam rencana tindakan, wajar, dan tidak artifisial dalam pelaksanaan siklus. Untuk memperoleh data yang diperlukan, hubungan antara presentasi dan rencana harus dipertimbangkan.

3. Observasi/Pengamatan

Pengamatan/observasi yang dimaksud adalah mengamati hal-hal yang dianggap positif dan negatif. Hasil pengamatan yang disajikan merupakan informasi yang memberikan kemungkinan adanya penarikan kesimpulan yang disertai dengan foto-foto.

4. Refleksi

Refleksi adalah tindakan yang melibatkan menyatakan kembali apa yang telah dilakukan. Refleksi dapat ditemukan pada apa yang berjalan dengan baik dan apa yang tidak, dan diputuskan untuk diperbaiki kembali di kelas. Keempat tahapan penelitian tindakan kelas tersebut merupakan komponen-komponen yang membentuk suatu siklus. Siklus adalah rangkaian kegiatan yang dimulai dari persiapan hingga tindakan, observasi, dan refleksi.

Untuk lebih refrensentatifnya data yang diperoleh, validitas dan reliabilitasnya tergantung pada teknik dan alat pengumpulan data yang digunakan. Teknik pengumpulan data yang digunakan pada penelitian ini adalahnon tes dan alatnya adalah observasi dan dokumentasi. 
1. Observasi

Dalam sebuah penelitian, observasi digunakan untuk memperoleh data. Observasi lapangan harus dilakukan untuk memperoleh informasi yang berkaitan dengan apa yang akan diteliti guna memahami status objek yang diteliti.

2. Dokumentasi

Juga penting untuk menerapkan prosedur dokumentasi selama pengumpulan data di lapangan agar data yang dikumpulkan melalui wawancara, kuesioner, dan observasi menjadi lebih kuat. "Data dokumen terdiri dari otobiografi, dokumen individu, catatan harian, catatan temuan, berita, dokumen keputusan, artikel, surat kabar, arsip organisasi, peta, gambar, foto, dan arsip. sejarah," saran Bogdan (dalam Wahono, 2003:58).

Teknik analisis data (FX. Sugiyono. 2008) yang digunakan untuk pengetahui peningkatan hasil belajar passing atas dalam permainan bola voli melalui metode variasi pada peserta didik kelas XI IPS SMA Negeri 2 Siak Hulu menggunakan teknik analisis deskriftif, dengan kriteria penilaian 1 sampai 4 (Kemendikbub RI,2017:27) , dengan menggunakan rumus sebagai berikut: Jumlah skor yang diperoleh

Nilai Keterampilan $=\frac{\text { Jumlah skor maksimal }}{\text { Jul }}$ X 100

\section{HASIL DAN PEMBAHASAN}

Data ini merupakan hasil data awal keterampilan passing atas permainan bola voli yang dikumpulkan dari siswa kelas XI IPS menggunakan lembar observasi sebelum tindakan. Hasil belajar siswa umumnya buruk. Hal ini mendorong peneliti untuk bertindak, menerapkan pendekatan variasi dalam pembelajaran passing atas. Data awal yang diperoleh dapat langsung dilihat pada tabel di bawah ini.

Tabel 1. Hasil Awal Belajar Passing Atas Dalam Permainan Bola Voli Pada Peserta Didik XI IPS SMA Negeri 2 Siak Hulu Sebelum Tindakan

\begin{tabular}{cccc}
\hline Interval & Kategori & Jumlah & Persentase \\
\hline $\mathbf{9 5 - 1 0 0}$ & Sangat Baik & 6 & 10.17 \\
$\mathbf{8 5 - 9 4}$ & Baik & 10 & 18.64 \\
$\mathbf{7 5 - 8 4}$ & Cukup & 10 & 18.64 \\
$\mathbf{6 0 - 7 4}$ & Kurang & 19 & 32.20 \\
$<\mathbf{6 0}$ & Kurang Sekali & 14 & 23.73 \\
& Jumlah & 59 & 100 \\
\hline
\end{tabular}

Enam siswa (10,17\%), sepuluh $(18,64 \%)$, sepuluh $(18,64 \%)$, sepuluh $(18,64 \%)$, sepuluh $(18,64 \%)$, sepuluh $(18,64 \%)$, sepuluh $(18,64 \%)$, sepuluh $(18,64 \%)$, dan empat belas $(14,20 \%)$. (23,73 persen). Kesimpulannya, hasil belajar passing bola voli siswa kelas XI IPS SMA Negeri 2 Siak Hulu tergolong rendah karena batas interval yang mencapai nilai mulai dari sedang sampai sangat baik hanya 26 orang (44,07 persen). Grafik di bawah ini menunjukkan hal tersebut.

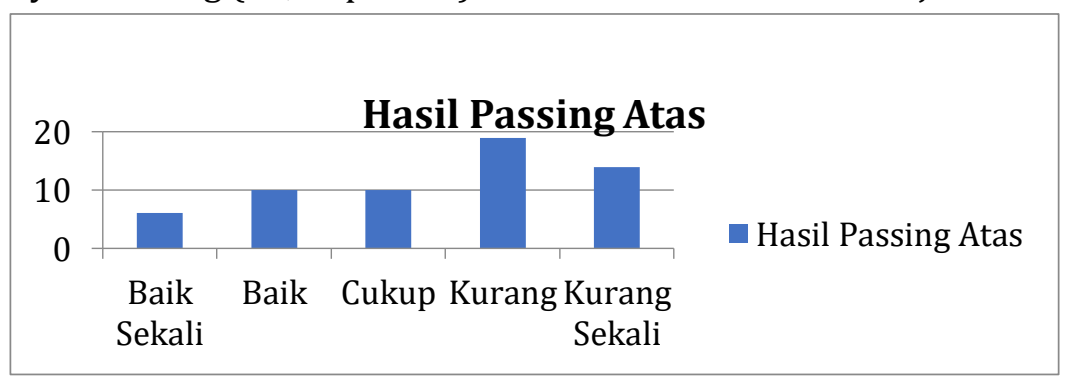

Gambar 1 Hasil Awal Belajar Passing Atas Dalam Permainan Bola Voli Pada Peserta Didik Kelas XI IS SMA Negeri 2 Sebelum Tindakan 
Sedangkan tingkat pertisipasi peserta didik hasil pengamatan sebelum tindakan tergambar pada tabel di bawah ini.

Tabel 2. Data Awal Pertisipasi Peserta Didik Kelas XI IPS Dalam Belajar Passing Atas Permainan Bola Voli Sebelum Tindakan

\begin{tabular}{|c|c|c|c|}
\hline Interval & Kategori & Jumlah & Persentase \\
\hline $95-100$ & Sangat Baik & 8 & 13.56 \\
\hline $85-94$ & Baik & 8 & 13.56 \\
\hline $75-84$ & Cukup & 14 & 23.73 \\
\hline $60-74$ & Kurang & 14 & 23.73 \\
\hline$<60$ & Kurang Sekali & 15 & 25.42 \\
\hline \multicolumn{2}{|c|}{ Jumlah } & 59 & 100 \\
\hline
\end{tabular}

Hasil observasi menunjukkan kurangnya hasil belajar dan partisipasi siswa dalam kegiatan pembelajaran passing atas permainan bola voli. Hanya 30 siswa atau 50,85\% yang berpartisipasi dalam pembelajaran sedang hingga sangat baik, sedangkan 29 siswa atau 49,15 persen yang berpartisipasi kurang dan kurang. Rendahnya data awal yang diperoleh memotivasi peneliti untuk menerapkan metode variasi dalam kegiatan pembelajaran dengan tujuan dapat mengatasi permasalahan yang dihadapi, dengan harapan dapat meningkatkan hasil belajar passing atas bola voli pada siswa kelas XI IPS SMA Negeri 2 Siak Hulu. Hal ini tentunya berpengaruh pada hasil belajarnya. Masalah ini harus diselidiki untuk menentukan akar penyebab dan solusi terbaik agar siswa secara keseluruhan dapat berpartisipasi dalam kegiatan pembelajaran passing atas.

\section{Siklus 1}

Dalam siklus 1, dilakukan melalui beberapa langkah-langkah., dimulai dari perencanaan kegiatan pembelajaran, menyusun perangkat pembelajaran, dan menentapkan metode variasi yang akan dilakukan dalam kegiatan pembelajaran passing atas.

\section{a. Proses pembinaan}

Prosedur pembinaan dilakukan dalam satu siklus berkesinambungan yang dinamakan siklus 1 untuk meningkatkan hasil belajar passing atas permainan bola voli pada siswa kelas XI IPS SMA Negeri 2 Siak Hulu. Jadwal pertemuan dan penelitian disesuaikan dengan jadwal materi pembelajaran yang diinginkan oleh mahasiswa dan peneliti bekerjasama. Pendekatan variasi digunakan untuk membina peningkatan hasil belajar passing atas permainan bola voli, yang terdiri dari langkah-langkah sebagai berikut:

\section{Perencanaan}

Perencanaan tindakan dilakukan melalui metode variasi yang dilakukan oleh peserta didik kela XI IPS dalam kegiatan pembelajaran passing atas permainan bola voli.

Selanjutnya mempersiapkan segala sesuatu yang diperlukan untuk terlaksananya tindakan dengan baik. Maka perencanaan tindakan dilakukan dengan kegiatan sebagai berikut:

a). Menyiapkan silabus dan RPP sesuai materi pembelajaran

b). Mempersiapkan fasilitas dan sarana pendukung yang diperlukan.

c). Menyiapkan blanko pedoman ebservasi yang berkaitan dengan keterampilan passing atas dan blanko observasi partisifasi peserta didik dalam pembelajaran

d). Menyiapkan pedoman penilaian hasil observasi

e). Menyiapkan bentuk latihan metode variasi pasing atas baik secara individu maupun kelompok.

2. Pelaksanaan

a). Menganalisis penyusunan perencanaan pembelajaran.

b). Melakukan tindakan berupa latihan gerakan dalam bentuk variasi latihan. 
c). Mengamati pelaksanaan pembelajaran yang dilakukan peserta didik

d). Membimbing pelaksanaan latihan pembelajaran, antara lain:

1). Guru memberikan apersepsi untuk memberi motivasi terhadap peserta didik

2). Guru menjelaskan manfaat metode variasi agar peserta didik mengetahui apa yang menjadi tujuan pembelajaran serta kegiatan-kegiatan apa yang akan dilakukan dalam pembelajaran yaitu melakukan latihan passing atas secara sendiri dan melakukan passing atas berpasangan

3). Guru membantu siswa yang menemui kesulitan dalam kegiatan pembelajaran

4). Menutup kegiatan pembelajaran merupakan ulasan mengenai kegiatan-kegiatan sebelumnya, bisa berupa kesimpulan, kegiatan pendinginan serta evaluasi hasil pembelajaran. sehingga dapat menentukan tindakan selanjutnya.

3. Pengamatan

Agar pelaksanaan dapat mengatahui hambatan-hambatan dalam melakukan kegiatan pembelajaran, maka dilakukan observasi terhadap hambatan dalam melakukan metode variasi latihan passing atas sehingga diketahui bambatan sebagai berikut:

a). Masih banyak peserta didik yang belum melibatkan diri secara aktif dalam kegiatan latihan passing atas,

b). Peserta didik belum memiliki kesempatan yang lebih untuk melibatkan diri dalam kegiatan pembelajaran.

c). Kurang variasi latihan sehingga perlu menambah variasi latihan dengan harapan lebih membuat peserta didik tertarik sehinggga terlibat secara utuh dalam kegiatan pembelajaran.

d). Mendokmentasikan kegiatan pembelajaran.

4. Refleksi

Pada kegiatan refleksi dilakukan penyusunan rencana pembelajaran pada siklus berikutnya.

b. Perilaku subjek penelitian

Dari hasil penelitian lapangan terhadap peningkatan hasil belajar passing atas permainan bola voli siswa kelas XI IPS terlihat bahwa perilaku tersebut ditunjukkan oleh subjek penelitian. Semua aktivitas siswa dalam melakukan latihan yang beragam, termasuk aktivitas siswa dalam kegiatan pembelajaran passing atas, dipermasalahkan. Perilaku subjek yang diamati adalah sebagai berikut:

1). Peserta didik mulai meningkatkan perhatian terhadap materi yang diberikan guru, maksudnya adalah motivasi atau keterlibatan peserta didik dalam pembelajaran lebih meningkat. Ini akan menunjukkan pada peningkatan keterampilan passing atas dalam permianan bola voli pada peserta didik dapat dijadikan sebagai acuan dalam peningkatan hasil belajar. Namun masih ada peserta didik yang belum mau terlibat secara aktif dalam kegiatan pembelajaran.

2). Timbulnya perilaku positif terhadap pembelajaran yaitu peserta didik memiliki kesempatan untuk belajar sesuai dengan tingkat perkembangan dan kemampuannya. Sehingga peserta didik dapat memecahkan masalah-masalah yang dihadapi di dalam menguasai teknik passing atas dalam permainan bola voli.

3). Peserta didik ada yang lebih memilih sikap apatis terhadap materi yang dibahas serta hanya menerima begitu saja apa yang diberikan guru terutama peserta didik putri yang kurang suka dengan materi passing atas dalam permainan bola voli karena dianggap tidak menarik sehingga belum mau terlihat secara aktif dalam kegiatan pembelajaran yang pperlu untuk diperhatiakn pada siklu berikutnya.

c. Hasil Kerja

Temuan strategi variasi yang digunakan untuk meningkatkan hasil belajar passing atas permainan bola voli pada siswa kelas XI IPS SMA Negeri 2 Siak Hulu. Hasil penelitian menunjukkan 11 siswa mendapat nilai sangat baik (18,64 persen), 16 siswa mendapat nilai baik (27,12 persen), 16 siswa mendapat nilai sedang (27,12 persen), 8 siswa mendapat nilai kurang 
(13,568 persen), dan 8 siswa mendapat nilai sangat kurang. hasil belajar (13,565 persen). Terjadi peningkatan hasil belajar. Peningkatan hasil belajar passing atas terlihat jelas pada tabel di bawah ini berdasarkan siklus 1 .

Tabel 3. Peningkatan Hasil Belajar Passing Atas Dalam Permainan

Bola Boli Melalui Metode Variasi Pada Peserta Didik Kelas IPS SMA Negeri 2 Siak Hulu Pada Siklus 1

\begin{tabular}{cccc}
\hline Interval & Kategori & Jumlah & Persentase \\
\hline $\mathbf{9 5 - 1 0 0}$ & Sangat Baik & 11 & 18.64 \\
\hline $\mathbf{8 5} \mathbf{- 9 4}$ & Baik & 16 & 27.12 \\
\hline $\mathbf{7 5 - 8 4}$ & Cukup & 16 & 27.12 \\
\hline $\mathbf{6 0 - 7 4}$ & Kurang & 8 & 13.56 \\
\hline$<\mathbf{6 0}$ & Kurang Sekali & 8 & 13.56 \\
\hline & Jumlah & 59 & 100 \\
\hline
\end{tabular}

Hasil tindakan yang dilakukan pada siklus 1 menunjukkan adanya peningkatan hasil belajar passing atas bola voli pada siswa kelas XI IPS yang menggunakan metode variasi, dengan peningkatan nilai sebesar 43 orang atau 72,88 persen dibandingkan sebelumnya hanya 26 orang (44,07 persen). persen) berdasarkan data awal. Dari hasil tersebut dapat kita amati bahwa terdapat peningkatan hasil belajar passing atas permainan bola voli siklus 1 jika dibandingkan dengan hasil data awal sebelum tindakan. Seperti terlihat pada grafik di bawah ini, terjadi peningkatan hasil belajar passing atas dari data awal sebelum tindakan ke data akhir setelah tindakan sebesar 17 siswa atau sebesar 28,81 persen pada siklus 1 .

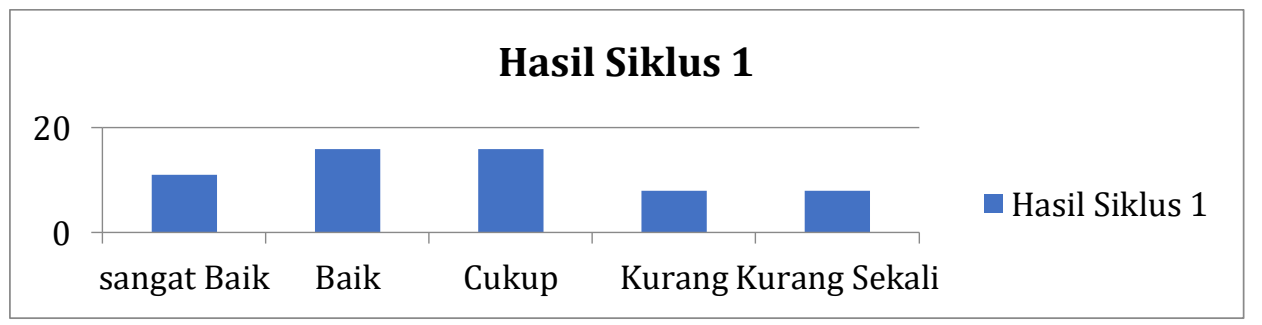

Gambar 2. Peningkatan Hasil Belajar Passing Atas Dalam Permainan Bola Voli Melalui Metode Variasi Pada Peserta Didik Kelas XI IPS SMA Negeri 2 Siak Hulu Pada Siklus 1

Terjadi peningkatan partisipasi siswa dalam kegiatan pembelajaran. Beberapa siswa, khususnya siswa perempuan, tidak menyukai konten over-passing dalam bola voli karena dianggap tidak sedap dipandang, seperti terlihat pada tabel di bawah ini.

Tabel 4. Peningkatan Partisipasi Peserta Didik Kelas XI IPS dalam Pembelajaran Passing Atas Melalaui Metode Variasi Pada Siklus 1

\begin{tabular}{ccccc}
\hline No & Interval & Kategori & Jumlah & Persentase \\
\hline 1 & $95-100$ & Sangat Baik & 14 & 23.73 \\
\hline 2 & $85-94$ & Baik & 10 & 16.95 \\
\hline 3 & $75-84$ & Cukup & 20 & 33.90 \\
\hline 4 & $60-74$ & Kurang & 10 & 16.95 \\
\hline 5 & $<60$ & Kurang Sekali & 5 & 8.47 \\
\hline \multicolumn{7}{r}{ Jumlah } & & 59 & 100 \\
\hline
\end{tabular}

Diperoleh data bahwa peserta didik yang memperoleh interval nilai dengan kategori sangat baik sampai nilai cukup sebanyak 44 orang dengan persentase $74.587 \%$, , Untuk nilai kurang dan kurang sekali sebanyak 15 orang (25.42\%),. Terjadi peningkatan partisipasi peserta didik dalam kegiatan pembelajaran bila dibandingkan dengan kegiatan sebelum tindakan secara jelas tergambar pada grafik 3 . 


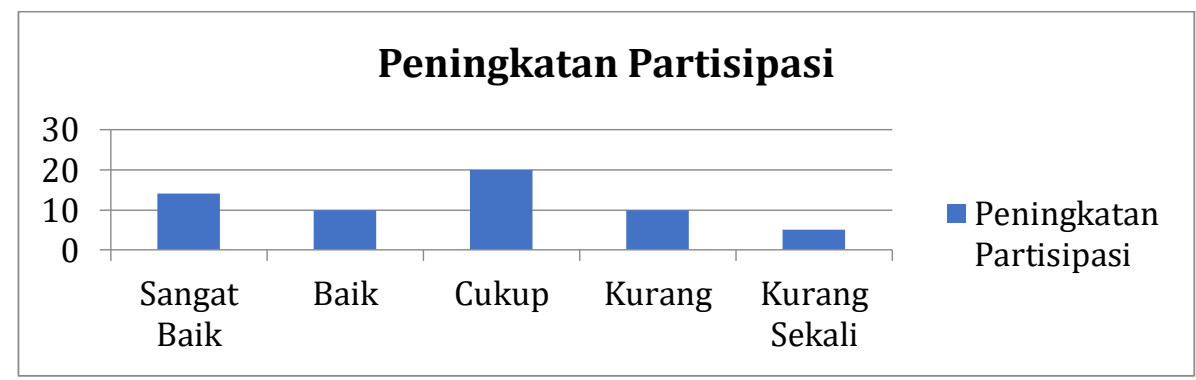

Gambar 3. Peningkatan Partisipasi Peserta Didik Dalam Pembelajaran Passing Atas Peserta didik Kelas XI IPS SMA Negeri 2 Siak Hulu Pada Siklus 1

Partisipasi siswa dalam permainan bola voli kelas XI IPS SMA Negeri 2 Siak Hulu akan mempengaruhi kualitas pembelajaran passing atas sehingga mempengaruhi hasil belajar. Untuk menghindari masalah ini, kembali ke solusi di siklus 2 .

\section{Guru}

Guru perlu menambah variasi latihan passing atas dalam kegiatan pembelajaran yang lebih menyenangkan dan lebih menarik perhatian peserta didik. Guru harus lebih memperhatikan dan lebih memberikan kesempatan kepada peserta didik untuk lebih aktif di dalam kegiatan pembelajaran yang akan dilaksanakan pada siklus 2 .

\section{Siklus 2}

Pelaksanaan tindakan pada siklus 2 sama dengan siklus 1, yaitu melalui langkah-langkah sebagai berikut :

\section{a. Perencanaan}

Merencanakan kembali, melaksanakan, dan mengamati kegiatan pembelajaran di kelas. Berikut pendekatan yang digunakan untuk meningkatkan hasil belajar passing atas permainan bola voli siswa kelas XI IPS SMA Negeri 2 Siak Hulu:

1) Kegiatan awal pembelajaran, yaitu kegiatan pembuka pembelajaran atau apersepsi

2) Kegiatan pembelajaran / proses pembelajaran, yaitu kegiatan inti yang merupakan kegiatan pembelajaran melalui metode variasi. Diawali deengan menjelaskan kembali maksud dan tujuan latihan melalui metode variasi agar peserta didik kembali mengatahui apa yang menjadi tujuan pembelajaran serta kegiatan-kegiatan yang akan dilakukan peserta didik dalam pembelajaran passing atas dalam permainan bola voli. Melalui variasi latihan berpasangan dan dalam bentuk permainan.

3) Kegiatan penutup merupakan ulasan mengenai kegiatan-kegiatan sebelumnya, bisa berupa kesimpulan serta evaluasi hasil pembelajaran sehingga dapat menentukan kebijakan guru selanjutnya.

b. Tindakan

1) Proses pembinaan

Proses pembinaan difokuskan pada kelemahan-kelemahan yang ditemui pada siklus 1 untuk mencarikan solusinya. Jadwal pelaksanaan siklus 2 tetap disesuaikan dengan jadwal pelajaran guru yang bersangkutan yang ditetapkan oleh SMA Negeri 2 Siak Hulu.

1) Guru harus bersikap terbuka yaitu kesediaan dalam mempertimbangkan masalahmasalah yang terjadi di dalam kelas dan terbuka terhadap gagasan-gagasan baru yang dikemukakan oleh peserta didik.

2) Guru senantiasa memelihara minat dan perhatian peserta didik di dalam pembelajaran serta mencari cara - cara untuk memperbaiki keadaan di dalam kegiatan pembelajaran terutama dalam menarik perhatian peserta didik dengan membuat variasi latihan passing atas dengan berpasangan dan dengan cara permainan sehingga diharapkan akan menarik perhatian peserta didik yang pada 
akhirnya membuat peserta didik mau terlibat lebih aktif dalam kegiatan pembelajaran.

Guru lebih bertanggungjawab untuk menerima segala akibat dari apa yang telah dipikirkan, dipilih, dan dialami di lapangan.

2) Perilaku subjek penelitian

Dengan menggunakan teknik varians, meningkatkan hasil belajar bola voli di SMA Negeri 2 Siak Hulu kelas X. Perilaku subjek penelitian terlihat jelas. Semua partisipasi siswa dalam kegiatan pendidikan dipertanyakan. Apa yang dilakukan subjek yang terpapar?

Meningkatkan minat anak-anak dalam permainan bola voli. Suasana belajar yang lebih baik mendorong siswa untuk menikmati latihan belajar. Dengan demikian, overpassing bola voli dapat ditingkatkan..

c. Hasil Pengamatan

Tabel 5: Siswa kelas XI SMA Negeri 2 Siak Hulu belajar passing dalam permainan bola voli dengan menggunakan strategi ragam.

Tabel 5. Hasil Belajar Ketuntasan Atas Peserta didik XI IPS SMA Negeri 2 Siak Hulu Siklus 2

\begin{tabular}{ccccc}
\hline No & Interval & Kategori & Jumlah & Persentase \\
\hline 1 & $95-100$ & Sangat Baik & 16 & 27.12 \\
\hline 2 & $85-94$ & Baik & 20 & 33.90 \\
\hline 3 & $75-84$ & Cukup & 17 & 28.81 \\
\hline 4 & $60-74$ & Kurang & 6 & 10.17 \\
\hline 5 & $<60$ & Kurang Sekali & 0 & 0 \\
\hline & Jumlah & & 59 & 100 \\
\hline
\end{tabular}

Data tabel 5 mendeskripsikan bahwa sebanyak 16 orang peserta didik memperoleh nilai baik sekali (27.12\%), 20 orang memperoleh nilai baik (33.90\%), sebanyak 17 orang peserta didik memperoleh nilai cukup (28.81\%), dan 6 orang peserta didik memperoleh nilai kurang (10.17\%), dan tidak ada siswa yang memperoleh nilai kurang sekali. Untuk lebih jelas hasil siklus 2 tergambar pada grafik 6.

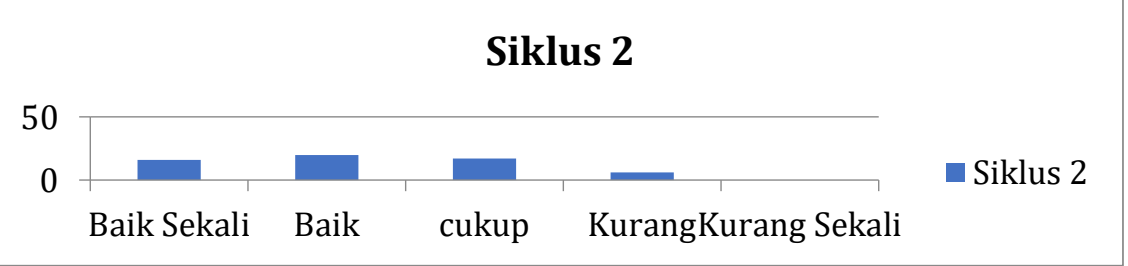

Gambar 4. Passing Atas Permainan Bola Voli Peserta XI IPS SMA Negeri 2 Siak Hulu Siklus 2

Kegiatan siklus 2 meningkatkan hasil passing bola voli di SMA Negeri 2 Siak Hulu kelas X IPS. Hasil belajar sebelum, selama, dan setelah tindakan meningkat drastis. Passing dalam bola voli meningkatkan pembelajaran sebesar 28,81 persen. Hasil belajar siklus 1 meningkat sebesar 72,88 persen sedangkan hasil belajar siklus 2 meningkat sebesar 89,83 persen. Secara keseluruhan, hasil meningkat. Seperti terlihat pada grafik 5, ketuntasan tertinggi siswa kelas XI IPS SMA Negeri 2 Siak Hulu adalah 89,83 persen..

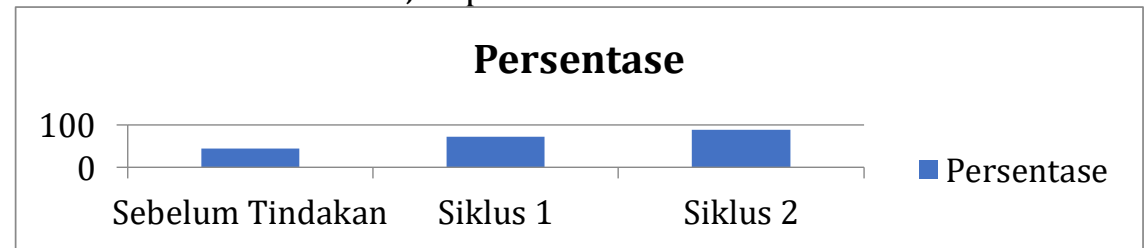

Gambar 5. Peningkatan Hasil Belajar Passing Atas Peserta XI IPS SMA Negeri 2 Siak Hulu Sebelum Tindakan, Siklus 1 dan Siklus 2 


\section{d. Refleksi}

Peneliti mengkaji kembali dan menganalisis dampak tindakan pada siklus 2 dan apakah masih ada permasalahan yang harus diselesaikan. Refleksi berusaha mengidentifikasi kekuatan dan kesalahan tindakan untuk memperbaikinya di siklus mendatang. Siklus 2 telah mengatasi kelemahan siklus 1 dalam hal:

1). Peserta didik.

Peserta didik dapat dilibatkan secara utuh melalui pelaksanaan metode variasi dalam pembelajaran. Dengan ketertarikan seorang peserta didik terhadap materi yang disajikan tidak hanya kerena latihan yang menyenangkan, tetapi sering mereka tertarik karena cara guru menyajikan materi seperti data tabel di bawah ini.

Tabel 6. Tingkat Partisipasi Peserta Didik Dalam Pembelajaran Passing Atas Dalam Permainan Bola Voli Kelas XI IPS SMA Negeri 2 Siak Hulu Pada Siklus 2

\begin{tabular}{|c|c|c|c|c|}
\hline No & Interval & Kategori & Jumlah & Persentase \\
\hline 1 & $95-100$ & Sangat Baik & 20 & 33.90 \\
\hline 2 & $85-94$ & Baik & 22 & 37.29 \\
\hline 3 & $75-84$ & Cukup & 12 & 20.34 \\
\hline 4 & $60-74$ & Kurang & 5 & 8.47 \\
\hline 5 & $<60$ & Kurang Sekali & 0 & 0 \\
\hline \multicolumn{3}{|c|}{ Jumlah } & 59 & 100 \\
\hline
\end{tabular}

Tabel 6 menunjukkan bahwa dari siswa yang mengikuti kegiatan pembelajaran passing atas dalam permainan bola voli, 54 siswa memperoleh nilai sangat baik sampai dengan cukup (91,53 persen). Seperti yang ditunjukkan pada grafik 8, 5 orang $(8,47 \%)$ mendapat skor lebih rendah dan lebih rendah. Pada siklus 1 dan 2, partisipasi siswa meningkat signifikan dibandingkan statistik pra tindakan. Partisipasi siswa dalam pembelajaran passing bawah pada permainan bola voli dengan pendekatan ragam meningkat dari 50,85\% menjadi 91,53 persen pada siklus 1 .

\section{Partisipasi Peserta Didik}

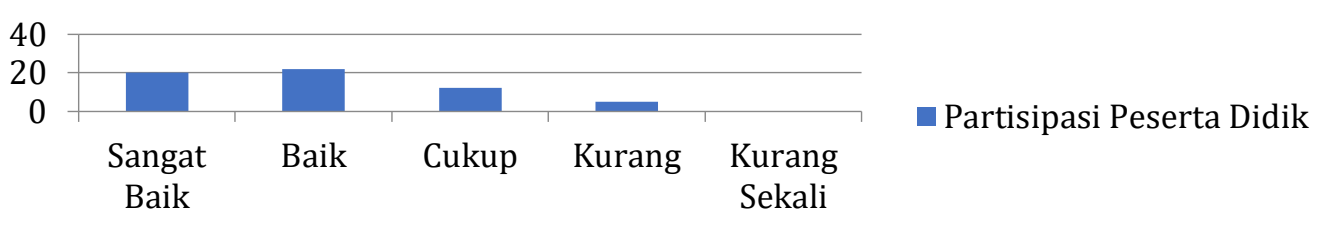

Gambar 6. Tingkat Partisipasi Peserta Didik Dalam Pembelajaran Passing Atas Kelas XI IPS SMA Negeri 2 Siak Hulu Pada Siklus 2

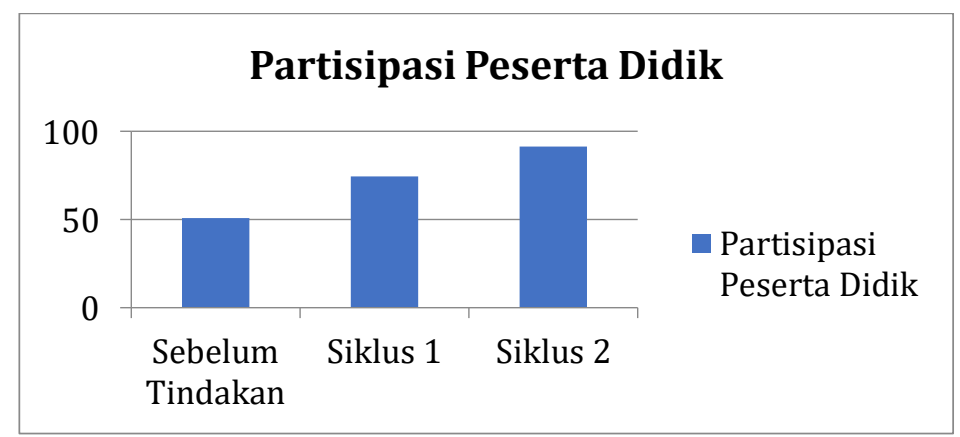

Gambar 7. Peningkatan Partisipasi Peserta Didik Dalam Pembelajaran Passing Atas Kelas XI IPS SMA Negeri 2 Siak Hulu sebelum Tindakan, Siklus 1 dan Siklus 2

2). Guru

Guru perlu memperbanyak variasi latihan passing atas. Ini dapat ditingkatkan dengan memperkaya ilmu pengetahuan tentang metode-metode pembelajaran sehingga guru lebih 
termotivasi dalam penyajian pembelajaran. Motivasi merupakan dorongan di mana seseorang yang mendorong seseorang melakukan aktivitas.

Motivasi merupakan sumber semangat untuk melakukan tindakan, sehingga kemampuan mengajar guru akan semakin baik sehingga mampu untuk mengatasi dan memberikan solusi terhadap permasalahan yang terjadi di dalam kelasnya. Dengan demikian diharapkan guru mampu meningkatkan hasil belajar peserta didiknya demi tercapainya tujuan yang telah ditetapkan.

Hasil penelitian menunjukkan adanya peningkatan hasil belajar passing bawah pada permainan bola voli dengan pendekatan ragam pada siswa kelas XI IPS SMA Negeri 2 Siak Hulu antara siklus 1 dan siklus 2 .

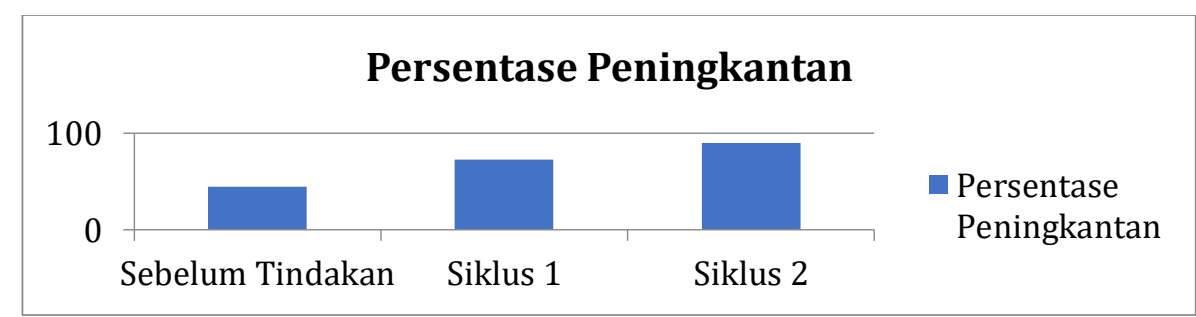

Gambar 8. Passing Atas Permainan Bola Voli: Peningkatan Hasil Belajar Siswa IPS SMA Negeri 2 Siak Hulu Sebelum Tindakan, Siklus 1 dan Siklus 2

Gambar 8 tersebut menunjukkan bahwa passing bola voli pada siswa kelas XI IPS SMA Negeri 2 Siak Hulu selama terapi meningkatkan hasil belajar pada dua siklus. Sebelum tindakan, hasil ketuntasan belajar siswa kelas XI IPS adalah 44,07 persen. Siklus 1 melihat peningkatan hingga 43 peserta, atau 72,88 persen, dalam hasil belajar. Diantara siklus 2, hasil belajar passing atas bola voli menggunakan berbagai cara meningkat sebesar 89,83 persen pada siswa kelas XI IPS SMA Negeri 2 Siak Hulu. SMA Negeri 2 Siak Hulu memiliki 27 siswa kelas XI IPS atau 45,76 persen dari jumlah keseluruhan.

Kenaikan ini dikaitkan dengan kemampuan instruktur untuk menciptakan lingkungan belajar yang menarik. Siswa termotivasi dan bersemangat untuk berpartisipasi dalam kegiatan pendidikan. Dengan menggunakan variasi, guru dapat menciptakan lingkungan belajar yang menyenangkan. Ini harus diulang sampai masalah teratasi.

Siswa sangat antusias dalam permainan bola voli. Penelitian ini juga menemukan bahwa penggunaan pendekatan yang bervariasi meningkatkan partisipasi siswa dalam kegiatan pembelajaran. Semua siswa berpartisipasi dengan antusias. Hampir setiap siswa mengikuti kegiatan pembelajaran lintas kurikuler.

Dengan menggunakan berbagai strategi, guru dapat melibatkan imajinasi siswa dalam proses pembelajaran. Mayoritas anak dapat menyelesaikan tugas guru. Grafik 9 menunjukkan peningkatan partisipasi belajar siswa dari data awal 30 orang $(50,85 \%)$ menjadi 44 orang (74,58\%) pada siklus 1 menjadi 54 orang $(91,53 \%)$ pada siklus 2 .

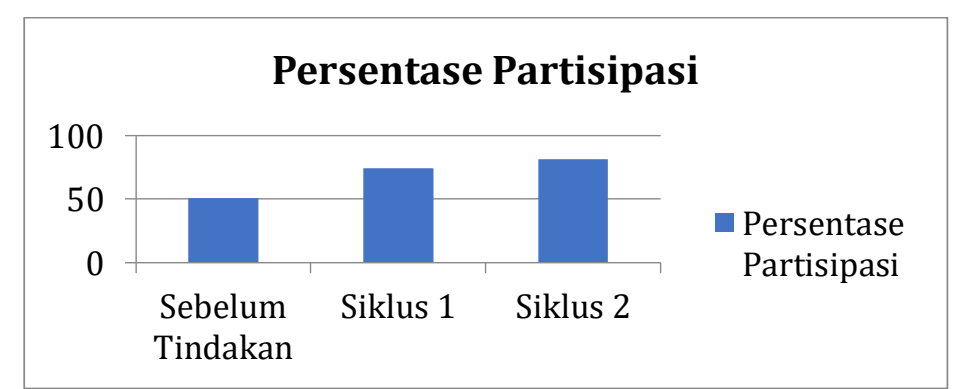

Gambar 9. Meningkatkan Partisipasi Siswa Dalam Pembelajaran Mengoper Bola Voli di SMA Negeri 2 Siak Hulu Sebelum Tindakan, Siklus 1 dan Siklus 2 
Siswa pada siklus 2 tidak hanya senang terlibat dalam pembelajaran, tetapi mereka juga tertarik dengan bagaimana guru mengomunikasikan pembelajaran. Hal ini ditunjukkan dengan keseriusan seluruh siswa dalam mengikuti pembelajaran dan memikul tanggung jawab yang besar dalam melaksanakan berbagai latihan overpassing dalam permainan bola voli, yang pada akhirnya berdampak pada peningkatan hasil belajarnya.

Pendekatan ragam digunakan untuk meningkatkan hasil belajar passing atas permainan bola voli siswa kelas XI IPS SMA Negeri 2 Saik Hulu, dan hasilnya positif, hanya 6 (10,17 persen) siswa yang memperoleh hasil belajar kurang baik. Dengan demikian, guru mampu memberikan pembelajaran yang berkualitas kepada siswa dalam rangka peningkatan mutu pendidikan di SMA Negeri 2 Siak Hulu.

\section{KESIMPULAN}

Hasil belajar passing atas permainan bola voli meningkat sebesar 72,88 persen pada siklus 1 dan 89,83 persen pada siklus 2 siswa kelas XI IPS SMA Negeri 2 Siak Hulu. Berdasarkan hasil belajar siswa kelas XI IPS yang mengikuti pelajaran passing dalam permainan bola voli, data sebelum tindakan hanya 50\%, siklus 1 sebesar 74,58\%, dan peningkatan partisipasi pelajaran passing sebesar 91,53\%. Meningkatkan hasil belajar, meningkatkan perhatian siswa terhadap kursus, dan memberikan kesempatan kepada anak-anak untuk belajar sesuai dengan tingkat perkembangan dan bakatnya dengan menggunakan strategi variasi yang seimbang. Hasil pendidikan yang lebih baik Peneliti dapat mengembangkan kreativitasnya untuk berinovasi dalam kegiatan pembelajaran dengan memvariasikan metodologi pembelajaran dan materi lainnya. Perlu penelitian lebih lanjut untuk meningkatkan hasil belajar passing atas dengan tetap fokus pada keterampilan bermain bola voli pagi siswa.

\section{DAFTAR PUSTAKA}

Adang, Suherman. 1999. Dasar-Dasar Penjaskes. Jakarta: Departemen Pendidikan dan Kebudayaan.

Arikunto, Suharsimi, 2010. Prosedur Penelitian, Edisi Revisi, Jakarta: PT.Rhineka Cipta.

Asmani,J.Ma'mur. 2011. Tips Pintar PTK: Penelitian Tindakan Kelas. Yogyakarta: Laksana.

Depdikbud. 1999. Penelitian Tindakan Kelas Action Research.Jakarta

FX. Sugiyono. 2008. Metode Penelitian Kuantitatif Kualitatif dan R\&D. Bandung: Alfabeta.

Harsono. 1988. Coaching dan Aspek-Aspek Psikologis dalam Coaching. Jakarta: CV. Tambak Kusuma.

Hera Lestari, Mikarsa. 2007. Pendidikan Anak di SD. Jakarta: Universitas Terbuka.

Kemendikbud. 2016. Buku Guru: Pendidikan Jasmani, Olahraga, dan Kesehatan Kelas XI. Jakarta: Kementerian Pendidikan dan kebudayaan.

Kemendikbud. 2017. Pendidikan Jasmani, Olahraga, dan Kesehatan Kelas XI (Edisi Revisi). Jakarta: Kementerian Pendidikan dan kebudayaan.

Lutan. Rusli. 1998. Belajar Keterampilan Motorik. Pengantar Teori dan Metode. Jakarta: Depdikbud. Dirjen Dikti, PP LPTK

Ma'mun, Amung dan Toto Subroto. 2001. Pendekatan Keterampilan Taktis Salam Pembelajaran Bola Voli : Konsep dan Metode. Pembelajaran. Jakarta: Direktorat Jenderal Olahraga Depdiknas.

Mulyasa. 2010. Menjadi Guru Profesional Menciptakan Pembelajaran Kreatif dan Menyenangkan. Bandung: PT. Remaja Rosdakarya Offset.

Suharsono. 1982. Permainan dan Metodik Untuk SGO. Jakarta: Percetakan Negara RI.

Suparlan. Dkk. (2008. PAKEM: Belajar Aktif, Kreatif, Efektif, Menyenangkan. Bandung: PT.Ganesindo.

Syafrudin. 2011. Ilmu Kepelatihan Olahraga.Padang : UNP, Pres.

Usman, M. Uzer. 2011. Menjadi Guru Profesional. Bandung: PT.Remaja Rosdakarya Offset. 